\title{
PENGARUH PIUTANG USAHA DAN HUTANG USAHA TERHADAP ARUS KAS OPERASI PADA PT DUNIA EXPRESS TAHUN 2016-2017
}

\author{
Gery Efendi ${ }^{1}$, Saprudin ${ }^{2}$ \\ Sekolah Tinggi Ilmu Ekonomi Jayakarta \\ Jakarta, Indonesia \\ gery0380@gmail.com, saprudin@stie.jayakarta.ac.id
}

\begin{abstract}
ABSTRAK
Piutang Usaha adalah sejumlah tagihan yang akan diterima oleh perusahaan (umumnya dalam bentuk kas) dari pihak lain, baik sebagai akibat penyerahan barang dan jasa secara kredit. Sedangkan Utang Usaha adalah kewajiban perusahaan untuk membayar sejumlah uang / jasa / barang di masa mendatang kepada pihak lain akibat transaksi yang dilakukan di masa lalu. Sedangkan Arus Kas Operasi adalah suatu laporan tentang aktivitas penerimaan dan pengeluaran kas perusahaan dalam suatu periode tertentu, beserta penjelasan-penjelasan sumber penerimaan dan pengeluaran kas tersebut. Penelitian ini bertujuan untuk menganalisis Piutang Usaha dan Utang Usaha terhadap Arus Kas Operasi pada PT Dunia Express tahun 2016-2017. Metode penelitian yang digunakan dalam penelitian ini adalah metode kualitatif . Pengujiannya dilakukan dengan menganalisis antara Piutang Usaha dan Utang Usaha, apakah berpengaruh terhadap Arus Kas Operasi dengan cara menghitung dengan persentase. Hasil dari penelitian ini adalah bahwa pengaruh peningkatan Piutang usaha terhadap arus kas berbanding terbalik dengan peningkatan utang usaha terhadap arus kas
\end{abstract}

Kata Kunci: Piutang Usaha, Utang Usaha, Arus Kas Operasi

\section{PENDAHULUAN}

Informasi yang cepat dapat membantu dalam mengambil keputusan. Untuk menjadi unggul dalam persaingan, perusahaan harus memiliki manajeman yang baik sehingga tujuan utama perusahaan dapat tercapai yaitu mencapai laba yang maksimal secara efektif, efisien dan ekonomis. Laba yang dihasilkan perusahaan tersebut berkaitan dengan kegiatan perusahaan yaitu penjualan.

Aktivitas penjualan dan pembelian merupakan aktivitas rutin yang dilakukan oleh suatu perusahaan. Masalah penjualan dan pembelian menjadi sangat penting karena mempengaruhi semua kegiatan perusahaan lainnya.
Penjualan kredit menimbulkan piutang usaha, sedangkan pembelian kredit akan menimbulkan hutang usaha. Untuk meningkatkan efisiensi dan efektivitas operasi perusahaan maka diperlukan sistem evaluasi terhadap sistem yang ada guna untuk mendapatkan informasi akuntansi pengelolaan piutang dan hutang yang baik.

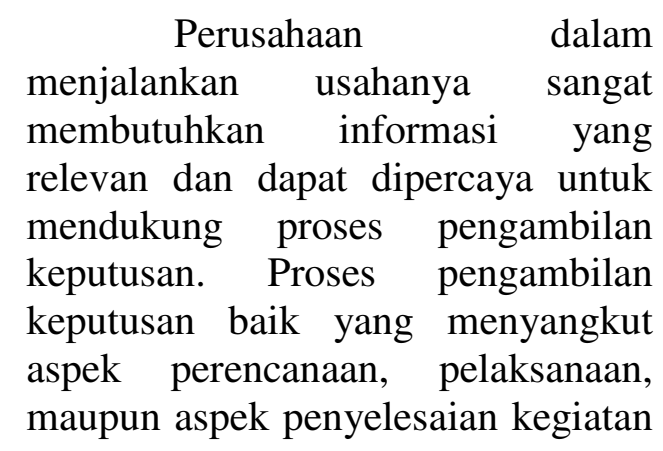


perusahaan. Informasi akuntansi merupakan bagian terpenting dari seluruh informasi yang diperlukan manajeman.

PT Dunia Express merupakan sebuah perusahaan jasa Freight Forwarder yang bergerak dibidang Pengurusan Jasa Kepabeanan (PPJK). Karena perusahaan hampir melakukan transaksi setiap harinya maka perusahaan memerlukan informasi yang cepat dan tepat agar keputusan dapat segera diambil, perusahaan mulai menerapkan sistem informasi akuntansi. Perusahaan harus tetap berusaha mempertahankan kelangsungan usahanya dimasa yang akan datang. Usaha yang dilakukan pasti memiliki kemampuan untuk menghasilkan keuntungan. PT Dunia Express dalam melakukan transaksi penjualan dan pembelian baik secara tunai maupun kredit akan dicatat sebagai piutang usaha dan hutang usaha apakah mempengaruhi arus kas perusahaan.

Transaksi penjualan dan pembelian secara kredit merupakan transaksi yang cukup tinggi terjadinya dalam suatu perusahaan. Sehingga muncul piutang usaha dan hutang usaha yang meningkat. Permasalahan terjadi saat piutang usaha meningkat dan customer belum membayar sesuai jatuh tempo. Pada saat tersebut, perusahaan mau tidak mau harus tetap menyediakan uang tunai untuk keperluan operasional perusahaan. Untuk tetap dapat mempertahankan kelangsungan usahanya, PT Dunia Express dapat meminjam uang kepada entitas perusahaan lain yang masih dalam lingkup satu grup usaha, tanpa harus membuat perjanjian kapan jatuh tempo nya dan tidak dikenakan bunga. (Menurut
Supervisor Finance, Ibu Elly Dwiyanti:2018)

\section{KAJIAN LITERATUR}

Menurut Rudianto (2018:98) Pengertian Piutang adalah klaim perusahaan atas uang, barang dan jasa kepada pihak lain akibat transaksi dimasa lalu. Tagihan yang tidak disertai janji tertulis disebut piutang, sedangkan tagihan yang disertai janji tertulis disebut wesel.

Menurut Kieso (2014:312) Istilah piutang didefinisikan sebagai jumlah yang dapat ditagih dalam bentuk uang dari seseorang atau perusahaan lain.

Menurut Carl S.Warren (2014:451) Piutang adalah seluruh uang yang diklaim terhadap entitas lain, termasuk perseorangan, perusahaan, dan organisasi lain.

Selain pendapat di atas, Hery (2014:202) mengatakan: Istilah piutang mengacu pada sejumlah tagihan yang akan diterima oleh perusahaan (umumnya dalam bentuk kas) dari pihak lain, baik sebagai akibat penyerahan barang dan jasa secara kredit (untuk piutang pelanggan yang terdiri atas piutang usaha dan memungkinkan piutang wesel) memberikan pinjaman (untuk piutang karyawan, piutang debitur yang biasanya langsung dalam bentuk piutang wesel dan piutang bunga), maupun sebagai akibat kelebihan pembayaran kas kepada pihak lain (untuk piutang pajak).

Berdasarkan pengertian diatas, penulis menyimpulkan bahwa, pada dasarnya Piutang adalah Sejumlah uang yang masih berada di pihak lain, setelah kita melakukan penjualan barang/jasa kepada pihak tersebut.

Menurut Hery (2014:206), Pengakuan piutang usaha sering berhubungan dengan pengakuan 
pendapatan. Karena pengakuan pendapatan pada umumnya dicatat ketika proses menghasilkan laba telah selesai dank as terealisasi atau dapat direalisasi, maka piutang yang berasal dari penjualan barang umumnya diakui pada waktu hak milik atas barang beralih ke pembeli. Karena pada saat peralihan hak dapat bervariasi sesuai dengan syarat-syarat penjualan maka piutang lazimnya diakui pada saat barang dikirimkan ke pelanggan. Sedangkan piutang untuk jasa kepada pelanggan semestinya diakui pada saat jasa itu dilaksanakan.

Menurut Rudianto (2018:211)

Sesuai dengan Standar Akuntansi Keuangan yang berlaku di Indonesia, piutang dicatat dan diakui sebesar jumlah bruto (nilai jatuh tempo) dikurangi dengan tafsiran jumlah yang tidak akan diterima. Itu berarti piutang harus dicatat sebesar jumlah yang diharapkan akan dapat ditagih. Karena itu berkaitan dengan pengelolaan piutang, perusahaan harus membuat suatu cadangan piutang tidak tertagih yang merupakan taksiran jumlah piutang yang tidak akan dapat ditagih dalam periode tersebut.

Dalam membuat Cadangan Kerugian Piutang/ piutang tidak tertagih terdapat dua dasar utama yang dapat digunakan yaitu:

a. Jumlah Penjualan (persentase tertentu dari penjualan)

b. Saldo Piutang

Menurut Rudianto (2018:214) Biasanya Cadangan Kerugian Piutang ditetapkan pada awal periode akuntansi, dan cadangan kerugian piutang merupakan suatu taksiran besarnya piutang yang tidak dapat ditagih pada suatu periode akuntansi. Ada 2 metode untuk menghapus suatu piutang yaitu Metode Cadangan
Kerugian Piutang dan Metode Penghapusan Langsung

Menurut Rudianto (2018: 275)

Utang adalah kewajiban perusahaan untuk membayar sejumlah uang / jasa / barang di masa mendatang kepada pihak lain akibat transaksi yang dilakukan di masa lalu.

Menurut Hery (2014 : 294) Utang Usaha adalah kewajiban yang diperkirakan akan dibayar dengan menggunakan asset lancar atau menciptakan kewajiban lancar lainnya dan harus segera di lunasi dalam jangka waktu kurang dari satu tahun.

Menurut Carl S. Warren (2014: 457) Utang merupakan kewajiban untuk membayar yang dicatat sebagai liabilitas oleh debitur. Utang Usaha berasal dari pembelian barang atau jasa untuk digunakan dalam kegiatan operasi perusahaan atau untuk membeli persediaan barang untuk dijual kembali.

Berdasarkan pengertian diatas, penulis menyimpulkan bahwa Utang usaha adalah kewajiban membayar sejumlah uang kepada kreditur dimasa yang akan datang, atas transaksi yang terjadi di masa lalu secara kredit.

Menurut Rudianto (2018: 194)

Kas adalah alat pembayaran yang dimiliki perusahaan dan siap digunakan untuk investasi maupun menjalankan operasi perusahaan setiap saat dibutuhkan. Karena itu, kas mencakup semua alat pembayaran yang dimiliki perusahaan yang disimpan di bank maupun di perusahaan.

Menurut PSAK (2008:2.2) arus masuk dan arus keluar kas atau setara kas. Walaupun terdapat banyak aktivitas yang dilakukan perusahaan dengan berbagai keunikan produknya, secara umum, semua aktivitas 
perusahaan dapat dikelompokkan kedalam tiga kelompok aktivitas utama berkaitan dengan penyusunan laporan arus kas. Ketiga kelompok aktivitas tersebut antara lain Menurut Rudianto (2018:60) :

a. Aktivitas Operasi

Berbagai aktivitas yang
berkaitan dengan upaya
perusahaan untuk menghasilkan
produk sekaligus semua upaya
yang terkait dengan menjual
produk tersebut. Artinya, semua
aktivitas yang berkaitan dengan
upaya untuk memperoleh laba
usaha dimasukkan kedalam
kelompok ini.

b. Aktivitas Investasi

Pengungkapan terpisah arus kas yang berasal dari aktivitas investasi perlu dilakukan sebab arus kas tersebut mencerminkan penerimaan dan pengeluaran kas sehubungan dengan sumber daya yang bertujuan menghasilkan pendapatan dan arus kas masa depan.

c. Aktivitas Pendanaan

Pengungkapan terpisah arus kas yang timbul dari aktivitas pendanaan perlu dilakukan sebab berguna untuk memprediksi klaim terhadap arus kas masa depan oleh para pemasok modal perusahaan.

Secara umum, terdapat dua metode dalam menyusun laporan arus kas, yaitu metode langsung dan metode tidak langsung. Baik metode langsung maupun metode tidak langsung.

Kerangka pemikiran dalam penelitian adalah sebagai berikut:

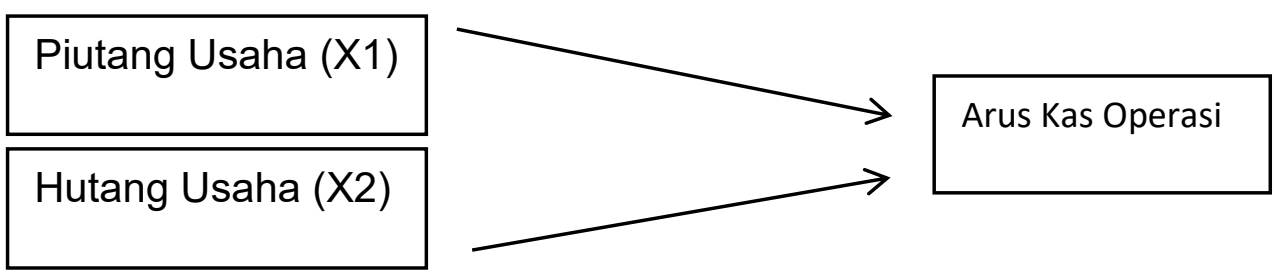

Adapun hipotesis dalam penelitian ini adalah

$\mathrm{H}_{1}$ : Piutang Usaha berpengaruh terhadap Arus Kas Operasi

$\mathrm{H}_{2}$ : Hutang Usaha berpengaruh terhadap Arus Kas Operasi

$\mathrm{H}_{3}$ :Piutang Usaha dan Hutang Usaha berpengaruh secara simultan terhadap Arus Kas Operasi

\section{III.METODE PENELITIAN}

Ditinjau dari tujuan
umumnya, jenis penelitian yang
digunakan adalah penelitian deskriptif
dan penelitian eksplanatif. Penelitian
deskriptif adalah penelitian yang menggambarkan analisis perhitungan arus kas yang dibuat perusahaan dalam meningkatkan likuiditas berdasarkan dengan perhitungan menurut ketetapan akuntansi yang berlaku di Indonesia. Sedangkan penelitian eksplanatif adalah untuk menjelaskan dan membuktikan hipotesis mengenai pengaruh piutang usaha dan hutang usaha terhadap arus kas operasi.

Berdasarkan sifat datanya, jenis penelitian yang digunakan adalah penelitian Kualitatif, Penelitian Kualitatif adalah metodologi kualitatif sebagai 
prosedur penelitian yang menghasilkan data yang bersumber dari wawancara langsung kepada bagian Piutang usaha (AR) dan Hutang Usaha (AP)

Penelitian merupakan cross sectional research, karena penelitian dilakukan dalam waktu relative singkat hanya dalam semester ganjil di tahun 2018.

$$
\text { Menurut Kerlinger }
$$

(2002,p.58) dalam Edi Riadi (2014:34) "Variabel Dependen/ Variabel Terikat adalah variabel yang dipandang atau diduga sebagai akibat. Variabel Terikat diberi simbol Y. Menurut Creswell (2005) dalam Edi Riadi (2014:34) Variabel Terikat (Dependen) adalah fluktuasi variabel yang bergantung pada fluktuasi variabel independen.

Dalam penelitian ini variabel dependen yang akan diteliti adalah Arus Kas Operasi. Arus Kas Operasi merupakan arus kas masuk dan arus kas keluar yang terjadi dalam suatu perusahaan. Adapun indicator yang digunakan adalah closing price per tahun

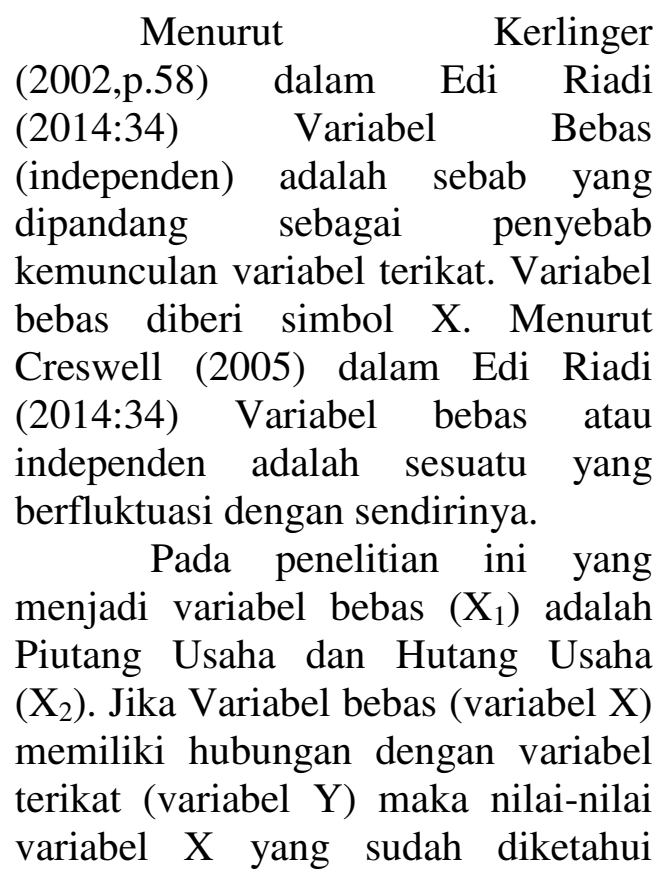

dapat digunakan untuk metaksir atau memperkirakan nilai-nilai Y.

Teknik pengumpulan data yang dilakukan dalam penelitian ini adalah:

1 Wawancara

2 Observasi

3 Dokumentasi

Menurut Amos Neolaka (2014:41) definisi Populasi adalah sumber utama untuk memperoleh data yang dibutuhkan dalam mengungkapkan fenomena atau realitas yang dijadikan fokus penelitian kita. Dalam kegiatan penelitian yang berkaitan dengan data selalu harus ada sumber data, dan sumber data berasal dari populasi. Dalam penelitian ini yang akan menjadi populasi adalah data piutang usaha dan hutang usaha periode tahun 2016-2017

Menurut Amos Neolaka (2014:42) Sampel adalah: bagian unsur populasi yang dijadikan objek penelitian. Sampel juga disebut wakil dari populasi yang ciri-cirinya akan diungkapkan dan akan digunakan untuk menaksir ciri-ciri populasi.

Sampel yang digunakan adalah data piutang usaha, hutang usaha dan arus kas. Sedangkan teknik pengambilan sampel yang digunakan adalah Purposive Sampling. Purposive Sampling merupakan cara pengambilan sampel berdasarkan pemilihan subyek yang kriteria spesifiknya ditetapkan oleh peneliti. Purposive sampling dalam penelitian ini adalah data piutang usaha dan hutang usaha pada tahun 2016-2017. Alasan pemilihan sampel dengan menggunakan Purposive sampling adalah karena tidak semua sampel memiliki kriteria yang sesuai dengan yang penulis tentukan.

Penelitian ini dilakukan pada PT Dunia Express dengan datang 
secara langsung pada perusahaan yang diteliti, berkonsultasi pada Staff yang berkaitan dengan materi penelitian. Mengambil data yang diperlukan kemudian melakukan analisis atas data yang dikumpulkan sebelumnya.

Menurut Sugiyono (2013:7) penelitian kualitatif dinamakan sebagai metode baru, sedangkan penelitian kuantitatif sebagai metode tradisional. Metode penelitian kualitatif sering disebut metode penelitian naturalistic karena penelitiannya dilakukan pada kondisi yang alamiah, disebut juga sebagai metode etnografi karena pada awalnya metode ini lebih banyak digunakan untuk penelitian dibidang antropologi budaya, dan data yang terkumpul dan analisisnya lebih bersifat kualitatif.

\section{HASIL DAN PEMBAHASAN}

PT Dunia Express adalah perusahaan berkembang, sehingga banyak kegiatan pemasukan dan pengeluaran yang terjadi selama dua tahun. Hal itu dilakukan untuk dapat memberikan pelayanan terbaik bagi para konsumen. Dalam menyajikan laporan arus kas, PT Dunia Express lebih memilih menggunakan menggunakan metode tidak langsung, karena lebih mudah dalam penyajian.

Rasio aktivitas yang akan dibahas pada penelitian ini yaitu rasio perputaran piutang dan periode penagihan piutang, \& rata rata piutang. Ketiga rasio ini biasanya digunakan dalam hubungan dengan analisis terhadap pengembalian piutang, karena memberi ukuran seberapa cepat piutang perusahaan berputar menjadi kas pada periode 2016 dan 2017.

Kenaikan/Penurunan Saldo Akun Laporan Arus Kas Tahun 2017

\begin{tabular}{|l|r|r|r|}
\hline \multicolumn{1}{|c|}{ Keterangan } & $\mathbf{2 0 1 7}$ & $\mathbf{2 0 1 6}$ & $\begin{array}{l}\text { Kenaikan (+) / } \\
\text { Penurunan (-) }\end{array}$ \\
\hline $\begin{array}{l}\text { Kas Bersih Diperoleh dari } \\
\text { (Digunakan untuk) } \\
\text { Aktivitas Operasi }\end{array}$ & & & \\
\hline $\begin{array}{l}\text { Kas Bersih Digunakan } \\
\text { untuk Aktivitas Investasi }\end{array}$ & $(6,381,795,479)$ & $(490,005,109)$ & $(5,891,790,370)$ \\
\hline $\begin{array}{l}\text { Kas Bersih Digunakan } \\
\text { untuk Aktivitas Pendanaan }\end{array}$ & $(1,000,000,000)$ & $(1,000,000,000)$ & 0 \\
\hline Kas Akhir & $\mathbf{3 8 2 , 6 5 0 , 1 0 0}$ & $\mathbf{1 8 , 2 8 5 , 6 7 7 , 8 8 5}$ & $\mathbf{( 1 7 , 9 0 3 , 0 2 7 , 7 8 5 )}$ \\
\hline
\end{tabular}

Kas bersih dari kegiatan Operasi tahun 2017 mengalami Penurunan sebesar Rp 12.011.237.415 dikarenakan penurunan dalam kegiatan operational, Kas bersih dari aktivitas investasi mengalami penurunan sebesar Rp 5.891.790.370, dan Kas bersih dari aktivitas pendanan tidak berubah dari tahun 2016 sampai 2017
Arus kas tahun 2017 mengalami penurunan, dari $\mathrm{Rp}$ 18.285.677.885 menjadi Rp 382.650.100. Hal ini disebabkan oleh kenaikan Piutang usaha pada Pihak Hubungan Istimewa pada tahun 2016 ke tahun 2017 sebesar Rp 1.844.646.476 dan Piutang Usaha Pihak ketiga pada tahun 2016 ke tahun 2017 sebesar Rp 5.863.364.414. Sedangkan Utang 
usaha pada Pihak Hubungan Istimewa mengalami penurunan pada tahun 2016 ke tahun 2017 sebesar 9.540.295.199 dan Utang Usaha Pihak Ketiga juga mengalami penurunan sebesar $\mathrm{Rp}$ 10.105.878.534.

Sesuai ketentuan, apabila Piutang usaha meningkat, maka arus kas akan menurun. Ini dikarenakan belum dibayarkannya tagihan tagihan yang sudah dikirimkan/ perusahaan sudah menyelesaikan pekerjaan, tetapi belum menerima pendapatan. Begitu pula sebaliknya, apabila Piutang usaha menurun, maka arus kas akan meningkat. Ini disebabkan, sudah dibayarkannya tagihan tagihan yang sudah dikirimkan/ perusahaan sudah menyelesaikan pekerjaan, dan sudah menerima pendapatan. Sedangkan untuk Utang usaha, ketentuannya apabila Utang Usaha meningkat, maka arus kas akan meningkat.Ini dikarenakan belum dibayarkannya tagihan tagihan dari supplier/pemasok. Sedangkan apabila Utang Usaha menurun, maka arus kas akan menurun. Ini didikarenakan sudah dibayarkannya tagihan tagihan dari supplier/pemasok

Maka dapat disimpulkan bahwa Piutang usaha dan Utang Usaha berpengaruh pada arus kas operasi PT Dunia Express pada tahun 2017. Dapat dibuktikan dengan presentase berikut ini:

\section{Persentase Kenaikan \& Penurunan Saldo Akun}

Aktivitas Operasi

\begin{tabular}{|l|c|c|r|r|}
\hline \multirow{2}{*}{ Keterangan } & \multicolumn{2}{|c|}{ TAHUN } & $\begin{array}{c}\text { Kenaikan (+) } \\
\text { /Penurunan (-) }\end{array}$ & \multirow{2}{*}{ Persentase } \\
\cline { 2 - 5 } & $\mathbf{2 0 1 7}$ & $\mathbf{2 0 1 6}$ & & \\
\hline Piutang Usaha & & & & $11.5 \%$ \\
\hline Hubungan Istimewa & $17,944,220,212$ & $16,099,573,736$ & $1,844,646,476$ & $55.8 \%$ \\
\hline Pihak Ketiga & $16,365,002,987$ & $10,501,638,573$ & $5,863,364,414$ & \\
\hline Hutang usaha & & & & $-35.0 \%$ \\
\hline Hubungan Istimewa & $17,736,321,539$ & $27,276,616,738$ & $(9,540,295,199)$ & $-39.3 \%$ \\
\hline Pihak ketiga & $874,356,181$ & $1,439,939,516$ & $(565,583,335)$ & \\
\hline
\end{tabular}

Dapat disimpulkan, piutang

usaha pihak ketiga mengalami kenaikan sebesar 11,5\%, ini berdampak pada penurunan arus kas sebesar Rp 19,824,606,968 dari tahun 2016 sebesar Rp 49,903,031,282 ke tahun 2017 sebesar $\mathrm{Rp}$ 30,078,424,314. Piutang usaha pihak ketiga mengalami kenaikan sebesar $55,8 \%$, ini berdampak pada penurunan arus kas sebesar $\mathrm{Rp}$ $19,824,606,968$ dari tahun 2016 sebesar Rp 49,903,031,282 ke tahun 2017 sebesar Rp 30,078,424,314.
Utang usaha pihak istimewa mengalami penurunan sebesar $35 \%$, ini berdampak pada penurunan arus kas sebesar $\operatorname{Rp~19,824,606,968~dari~}$ tahun $2016 \quad$ sebesar $\mathrm{Rp}$ 49,903,031,282 ke tahun 2017 sebesar Rp 30,078,424,314, utang usaha pihak ketiga mengalami penurunan sebesar 39,2\%, ini berdampak pada penurunan arus kas sebesar Rp 19,824,606,968 dari tahun 2016 sebesar Rp 49,903,031,282 ke tahun $2017 \quad$ sebesar $\mathrm{Rp}$ $30,078,424,314$.

Kenaikan/Penurunan Saldo Akun

Laporan Arus Kas Tahun 2016

\begin{tabular}{|c|c|c|c|}
\hline Keterangan & 2016 & 2015 & $\begin{array}{l}\text { Kenaikan (+) / } \\
\text { Penurunan (-) }\end{array}$ \\
\hline
\end{tabular}


Jurnal Akuntansi \& Perpajakan Jayakarta, Volume I, No. 1, Juli 2019

\begin{tabular}{|l|r|r|r|}
$\begin{array}{l}\text { Kas Bersih Diperoleh dari } \\
\text { (Digunakan untuk) }\end{array}$ & & \\
Aktivitas Operasi & $19,775,682,994$ & $17,033,204,068$ & $2,742,478,926$ \\
\hline $\begin{array}{l}\text { Kas Bersih Digunakan } \\
\text { untuk Aktivitas Investasi }\end{array}$ & $(490,005,109)$ & $(696,798,345)$ & $206,793,236$ \\
\hline $\begin{array}{l}\text { Kas Bersih Digunakan } \\
\text { untuk Aktivitas Pendanaan }\end{array}$ & $(1,000,000,000)$ & $(1,000,000,000)$ & 0 \\
\hline Kas Akhir & $\mathbf{1 8 , 2 8 5 , 6 7 7 , 8 8 5}$ & $\mathbf{1 5 , 3 3 6 , 4 0 5 , 7 2 3}$ & $\mathbf{2 , 9 4 9 , 2 7 2 , 1 6 2}$ \\
\hline
\end{tabular}

Kas bersih pada aktivitas operasi mengalami kenaikan sebesar Rp 2.742.478.926, kas bersih pada aktivitas investasi mengalami kenaikan sebesar Rp 206.793.236, kas bersih pada aktivitas pendanaan tidak mengalami perubahan pada tahun 2015-2016.

Arus kas pada 2016 mengalami kenaikan sebesar Rp 2.949.272.162, ini disebabkan oleh penurunan piutang usaha pada pihak hubungan istimewa pada tahun 2015 ke tahun 2016 sebesar Rp 4.257.777.775 dan penurunan piutang usaha pada pihak ketiga pada tahun 2015 ke tahun 2016 sebesar 1.044.444.441. Sedangkan Utang usaha pihak hubungan istimewa mengalami kenaikan pada tahun 2015 ke tahun 2016 sebesar Rp 822.222.221 dan utang usaha pihak ketiga juga mengalami kenaikan pada tahun 2015 ke tahun 2016 sebesar Rp 688.888 .889

Sesuai ketentuan, apabila Piutang usaha meningkat, maka arus kas akan menurun. Ini dikarenakan belum dibayarkannya tagihan tagihan yang sudah dikirimkan/ perusahaan sudah menyelesaikan pekerjaan, tetapi belum menerima pendapatan. Begitu pula sebaliknya, apabila Piutang usaha menurun, maka arus kas akan meningkat. Ini disebabkan, sudah dibayarkannya tagihan tagihan yang sudah dikirimkan/ perusahaan sudah menyelesaikan pekerjaan, dan sudah menerima pendapatan. Sedangkan untuk Utang usaha, ketentuannya apabila Utang Usaha meningkat, maka arus kas akan meningkat.Ini dikarenakan belum dibayarkannya tagihan tagihan dari supplier/pemasok. Sedangkan apabila Utang Usaha menurun, maka arus kas akan menurun. Ini didikarenakan sudah dibayarkannya tagihan tagihan dari supplier/pemasok

Maka dapat disimpulkan bahwa Piutang usaha dan Utang Usaha berpengaruh pada arus kas operasi PT Dunia Express pada tahun 2016. Ini dapat dibuktikan dengan tabel sebagai berikut:

\section{Persentase Kenaikan \& Penurunan Saldo Akun Aktivitas Operasi}


Jurnal Akuntansi \& Perpajakan Jayakarta, Volume I, No. 1, Juli 2019

\begin{tabular}{|c|c|c|c|c|}
\hline \multirow{2}{*}{ Keterangan } & \multicolumn{2}{|c|}{ TAHUN } & \multirow{2}{*}{$\begin{array}{c}\text { Kenaikan (+) } \\
\text { /Penurunan (-) }\end{array}$} & \multirow{2}{*}{ Persentase } \\
\hline & 2016 & 2015 & & \\
\hline \multicolumn{5}{|l|}{\begin{tabular}{|l|} 
Piutang Usaha \\
\end{tabular}} \\
\hline Hubungan Istimewa & $16,099,573,736$ & $20,357,351,511$ & $(4,257,777,775)$ & $-20.9 \%$ \\
\hline Pihak Ketiga & $10,501,638,573$ & $11,546,083,014$ & $(1,044,444,441)$ & \\
\hline \multicolumn{5}{|l|}{ Hutang usaha } \\
\hline \begin{tabular}{|l} 
Hubungan Istimewa \\
\end{tabular} & $27,276,616,738$ & $26,454,394,517$ & $822,222,221$ & $3.1 \%$ \\
\hline Pihak ketiga & $1,439,939,516$ & $1,573,272,848$ & $(133,333,332)$ & $-8.5 \%$ \\
\hline \begin{tabular}{l}
\multicolumn{1}{c}{ Dari } \\
usaha pihak \\
mengalami pe \\
ini berdampak \\
pada tahu \\
Rp6,487,238,6 \\
sebesar Rp43, \\
2016 sebesa \\
Piutang usaha \\
mengalami pe \\
berdampak pa \\
pada tahu \\
Rp6,487,238,6 \\
sebesar Rp43 \\
2016 sebesar F
\end{tabular} & $\begin{array}{l}\text { table diatas, } \\
\text { hubungan is } \\
\text { nurunan sebesar } \\
\text { pada kenaikan a } \\
\text { in } 2016 \\
679 \text { dari tahun } \\
, 415,792,603 \text { ke } \\
\text { ar Rp49,903,0 } \\
\text { pihak hubungan } \\
\text { nurunan sebesar } \\
\text { ada kenaikan ar } \\
\text { in 2016 } \\
679 \text { dari tahun } \\
, 415,792,603 \text { ke } \\
\text { Rp49,903,031,28 }\end{array}$ & $\begin{array}{l}\text { piutang } \\
\text { timewa } \\
20,9 \% \text {, } \\
\text { arus kas } \\
\text { sebesar } \\
2015 \\
\text { tahun } \\
31,282 . \\
\text { ketiga } \\
9 \% \text {, ini } \\
\text { rus kas } \\
\text { sebesar } \\
2015 \\
\text { tahun } \\
2 .\end{array}$ & \multicolumn{2}{|c|}{$\begin{array}{l}\text { Rp49,903,031,282. Utang usaha } \\
\text { pihak ketiga mengalami penurunan } \\
\text { sebesar 8,1\%, ini berdampak pada } \\
\text { penurunan arus kas pada tahun } 2016 \text {. } \\
\text { Bedasarkan perhitungan dari } \\
\text { rasio aktivitas pada PT Dunia } \\
\text { Express, berikut merupakan daftar } \\
\text { tabel hasil perhitungan rasio aktivitas: }\end{array}$} \\
\hline
\end{tabular}

Uraian Hasil Analisis Rasio Aktivitas pada

PT Dunia Express

\begin{tabular}{|l|r|r|r|}
\hline \multirow{2}{*}{ Keterangan } & \multicolumn{2}{|c|}{ Tahun } & \multirow{2}{*}{$\begin{array}{c}\text { Kenaikan/ } \\
\text { Penurunan }\end{array}$} \\
\cline { 2 - 3 } & 2016 & 2017 & 0 \\
\hline Rasio Perputaran Piutang Pihak Hubungan Istimewa & 3 & 3 & 2 \\
\hline Rasio Perputaran Piutang Pihak Ketiga & 5 & 3 & 0 \\
\hline Periode Penagihan Piutang Pihak Istimewa & 122 & 122 & 49 \\
\hline Periode Penagihan Piutang Pihak Ketiga & 73 & 122 & \\
\hline
\end{tabular}

1 Rasio Perputaran Piutang Usaha Pihak Hubungan Istimewa

Nilai rasio perputaran piutang usaha pihak hubungan istimewa pada PT Dunia Express tidak mengalami kenaikan maupun penurunan. Untuk standar perputaran piutang usaha yang telah ditetapkan adalah 4 (dimana jatuh tempo pembayaran piutang s/d 90 hari). Artinya nilai rasio ini belum bisa dikatakan mencapai target. Karena belum sesuai dengan kebijakan perusahaan. Dengan demikian dapat dikatakan bahwa investasi modal yang ditanamkan dalam piutang usaha pihak hubungan istimewa selama tahun 2016 dan 2017 belum terlaksana secara efisien. Ini berarti perusahaan belum maksimal dalam mengelola piutang yang dimiliki dan apabila kondisi ini tidak segera diantisipasi maka akan mengakibatkan kerugian bagi perusahaan.

2 Rasio Perputaran Piutang Usaha Pihak Ketiga 
Berbeda dengan piutang usaha pihak hubungan istimewa, piutang usaha pihak ketiga mengalami kenaikan dan mencapai target pada tahun 2017. Standar yang ditetapkan perusahaan adalah 4 (dimana jatuh tempo pembayaran piutang s/d 90 hari). Artinya nilai rasio ini sudah dapat dikatakan mencapai target. Dengan demikian, dapat dikatakan bahwa investasi modal yang ditanamkan dalam piutang usaha pihak ketiga sudah terlaksana dengan efisien.

3 Periode Penagihan Piutang Usaha Pihak Hubungan Istimewa

$$
\text { Periode penagihan }
$$
piutang usaha pihak hubungan istimewa pada PT Dunia Express tidak mengalami peningkatan maupun penurunan dari tahun 2016 sampai 2017. Standar periode penagihan piutang yang telah ditetapkan perusahaan adalah 90 hari (dimana jatuh tempo pembayaran piutang s/d 90 hari). Kondisi ni berarti menggambarkan adanya peningkatan waktu yang diperlukan perusahaan untuk mengubah piutang usaha menjadi kas dari yang seharusnya 90 hari menjadi 122 hari. Ini menunjukkan bahwa perusahaan belum mampu dalam mengelola piutang yang harus ditagih dan kondisi ini harus segera diantisipasi. Karena semakin tinggi rasio ini, berarti semakin lama waktu yang diperlukan untuk menagih piutangnya. Dengan kata lain, kemampuan penagihannya menjadi semakin kecil. Berarti jumlah dana yang terikat menjadi piutang semakin besar, sehingga kebutuhan modal kerja pun meningkat.
4 Periode Penagihan Piutang Usaha Pihak Ketiga

Berbeda dengan piutang usaha pihak hubungan istimewa, piutang usaha pihak ketiga mengalami penurunan periode penagihan piutang dari $2016 \mathrm{ke}$ 2017 menjadi 73 hari. Dimana standar yang ditetapkan perusahaan untuk penagihan adalah 90 hari (jangka waktu pembayaran/jatuh tempo piutang 90 hari) . Artinya nilai rasio ini sudah dapat dikatakan mencapai target. Dengan demikian, dapat dikatakan bahwa investasi modal yang ditanamkan dalam piutang usaha pihak ketiga sudah terlaksana dengan efisien.

Antara piutang usaha dan utang usaha sangat berpengaruh terhadap arus kas perusahaan terutama pada aktivitas operasi. Contohnya, pada Piutang Usaha, sebenarnya jika dari pihak customer mampu membayar secara rutin, uang pembayaran tersebut dapat dialihkan kedalam instrument investasi lainnya seperti deposito, reksadana, saham, agar perusahaan memperoleh bunga/deviden. Sedangkan jika hutang usaha kita bayarkan tepat waktu, maka dari pihak supplier akan percaya

\section{KESIMPULAN}

Berdasarkan pengamatan dan penelitian yang dilakukan pada masing-masing variabel yang diteliti, maka dapat disimpulkan sebagai berikut:

1 Secara Parsial, piutang usaha mempunyai pengaruh yang signifikan terhadap arus kas operasi, dibuktikan bahwa pada saat piutang usaha meningkat, arus kas operasi menurun dan pada saat 
Jurnal Akuntansi \& Perpajakan Jayakarta, Volume I, No. 1, Juli 2019

piutang usaha menurun, arus kas operasi meningkat.

2 Secara parsial, utang usaha mempunyai pengaruh yang signifikan terhadap arus kas operasi, dibuktikan bahwa pada saat utang usaha meningkat, arus kas operasi meningkat dan pada saat utang usaha menurun, arus kas operasi menurun.

3 Secara simultan, piutang usaha dan utang usaha berpengaruh terhadap arus kas operasi,.

\section{REFERENSI}

Weygandt, Jerry J, Dondald E . Kieso, Kimmel Paul D , Accounting Principles $7^{\text {th }}$ ed. Penerbit Salemba Empat, Jakarta, 2014.
Hery, Akuntansi Dasar 1 dan 2, Grasindo, Jakarta, 2017

Warren, Carl S, Reeve, James M, Duchac, Jonathan E, Suhardianto, Novrys, Pengantar Akuntansi Adaptasi Indonesia, Penerbit Salemba Empat, Jakarta 2014

Ikatan Akuntan Indonesia, Standar Akuntansi Keuangan, Penerbit Salemba Empat, Jakarta 2008

Neolaka, Amos, Metode Penelitian dan Statistik, Penerbit Rosda, Jakarta, 2014

Rudianto, Akuntansi Intermediate IFRS, Penerbit Erlangga, Jakarta, 2018

Riadi, Edi, Metode Statistika Parametrik \& Nonparametrik, Penerbit Pustaka Mandiri, Jakarta, 2016

Sugiyono. 2016. Metodologi Penelitian

Kualitatif, Kuantitatif dan $R \& D$.

Bandung: Alfabeta 